\title{
Assessing Naturalness in Northern Great Lakes Forests Based on Historical Land-Cover and Vegetation Changes
}

\author{
Urs Gimmi • Volker C. Radeloff
}

Received: 12 July 2012/ Accepted: 2 June 2013/Published online: 15 June 2013

(C) Springer Science+Business Media New York 2013

\begin{abstract}
The concept of naturalness was developed to assess to what degree landscapes represent a natural state. Protected areas are often regarded as the remnants of untouched landscapes although many landscapes commonly perceived as pristine have a long history of human impact. Here, we introduced a historical perspective into the concept of naturalness and the analysis of the effectiveness of protected areas by analyzing historical trajectories in land-cover and forest communities for the Pictured Rocks National Lakeshore on Michigan's Upper Peninsula (USA). Distribution of land-cover and forest community types was reconstructed for pre-settlement time (around 1850), the height of agricultural expansion (1928), and modern conditions (2000). Naturalness of the landscape was assessed by analyzing similarity between pre-settlement and current conditions and by assessing landscape continuity (1850-1928-2000). We compared changes in the strictly protected park core zone with those in the inland buffer zone with ongoing sustainable logging, and a not protected area adjacent to the park. Forest was the dominant land-cover type over the entire study period. We detected a gradient in land-cover continuity from the core zone ( $81 \%$ continuity) to the inland buffer zone (74\%) and the area outside the park $(66 \%)$. Northern hardwood was the dominating forest type in all time points with high
\end{abstract}

\footnotetext{
U. Gimmi $(\bowtie)$

Research Unit Landscape Dynamics, Swiss Federal Research Institute WSL, Zürcherstrasse 111,

8903 Birmensdorf, Switzerland

e-mail: urs.gimmi@wsl.ch

U. Gimmi · V. C. Radeloff

Department of Forest and Wildlife Ecology, University

of Wisconsin-Madison, 1630 Linden Drive,

Madison, WI 53706, USA
}

continuity $(76 \%)$. In contrast, pine forests show a more dynamic pattern with more than $50 \%$ of the initial forests switching to non-forest or early succession forest types by 1928. More than half of the study area was considered as "natural virgin" (no changes in land-cover and forest community type) with a higher portion within the park than in the adjacent area. In contrast, areas with low naturalness are more abundant outside the park. Our study demonstrates the value of integrating historical information into naturalness assessments and the results provide useful information for future park management. More broadly speaking, our study advances research on the effectiveness of protected areas, by going beyond simple measures of averted deforestation, and introducing approaches to directly measure naturalness.

Keywords Land-use history · Land-use change . Naturalness · Logging · Great Lakes · Protected areas

\section{Introduction}

Large parts of the Earth's terrestrial surface have been fundamentally altered by human land-use (Vitousek and others 1997; Foley and others 2005) with manifold ecological consequences ranging from habitat loss and fragmentation to changes in biogeochemical cycles (Goudie 2006). While it is known that most landscapes perceived as "pristine" or "virgin" have a long history of human impacts (Heckenberger and others 2003; Willis and others 2004), protected areas are often regarded as the last remnants of natural landscapes untouched by human activities (Sanderson and others 2002). This raises the question to what degree protected areas represent a natural state. To assess this question conservation scientists developed the 
concepts of naturalness (i.e., intactness or integrity of ecosystems; Anderson 1991; Angermeier 2000) and wildness (i.e., area free from human influence; Barry and others 2001). There are several approaches to measuring the naturalness of a landscape (Machado 2004). One important aspect of determining naturalness in a given landscape is the evaluation of its land-use history, i.e., how much a landscape has been transformed by human activities and whether legacies from historical land-use remain. In turn, land-use history can serve as an important criterion in the evaluation of conservation priority areas (Branquart and others 2008).

In land management, historical conditions are a reference point (Swetnam and others 1999) that provides vital information to set conservation targets (Foster and others 2003) and restoration priorities (Moore and others 1999; Bolliger and others 2004; Stein and others 2010). For North America, the vegetation conditions prior to Euro-American settlement are often used as a reference for natural conditions (Radeloff and others 2000). After the onset of settlement many regions experienced clearing of the natural landscape and agricultural occupation, and in some regions subsequent abandonment and recovery (Radeloff and others 1999; Ramankutty and others 2010). Analyses of forest change thus require long-term data to place patterns of recent reforestation in the larger context of earlier forest losses and relevant reference points.

The general pattern of forest loss followed by recovery is widespread in the developed world and known under the term of forest transition (Mather 1992; Rudel and others 2005). Initially, loss of forest cover is the result of both, resource exploitation and the conversion of forests to agricultural land-use. As societies develop, some farms are abandoned, especially those on poorer soils, and former farmers move to cities and work in other sectors. These abandoned farms then revert to forests either due to natural succession or deliberate forest planting (Radeloff and others 1999). However, the question is to which degree these regrowing forests indeed represent a return to an original, more natural state or not, and this depends in part on forest composition. In the extreme case, plantations, especially those with non-native species, are likely to differ substantially in their habitat attributes and ecosystem processes from prior natural forests (Meyfroidt and Lambin 2011; Brandt and others 2012). Furthermore, even where natural succession ensures the regeneration by native tree species, the tree species composition is often very different from the reference point (Radeloff and others 1999). This suggests that analyses of forest change over time should examine not just forest cover, but also forest composition as a proxy for naturalness, and that naturalness may be a good metric to introduce into the discussion about the effectiveness of protected areas (DeFries and others 2005;
Radeloff and others 2010), in order to be able to compare protected areas in different ecological settings.

Our goal here was to assess naturalness in the Pictured Rocks National Lakeshore (referred to as "Pictured Rocks" in the following) on Michigan's Upper Peninsula based on knowledge about historical changes in land-cover and forest communities. Pictured Rocks is an interesting case study because the park consists of a park core zone with a strict logging ban and an inland buffer zone with ongoing sustainable logging activities, and because Pictured Rocks' environmental history is typical for large areas in the U.S. that underwent forest exploitation followed by recovery.

Our primary hypothesis was that there is a gradient from highest naturalness in the park core zone to reduced naturalness in the park buffer zone and to lowest naturalness in the area outside the park boundary. The specific aims of our study were to (i) reconstruct land-cover and distribution of forest community types for three points in time (presettlement, height of agricultural expansion, and modern conditions), (ii) measure the magnitudes, rates, and trajectories of changes in land-cover and forest community classes and compare trends for the park core zone, the inland buffer zone, and the unprotected area adjacent to the park, and (iii) assess the naturalness of the current landscape based on our land-cover and forest change analyses.

\section{Data and Methods}

\section{Study Area}

Pictured Rocks National Lakeshore is designated as a category III park (natural monument) by the International Union for Conservation of Nature (IUCN, Dudley 2008). Pictured Rocks is located in the center of Michigan's Upper Peninsula and contains $67 \mathrm{~km}$ of Lake Superior's shoreline and almost 27,500 ha of post-glacial landscape within the transition zone between boreal forests of the northern latitudes and northern hardwood forests, a forest ecosystem type extending from southeastern Canada into the adjacent regions of the United States. The park consists of a 12,200 ha core zone (also called shoreline zone) and a 15,300 ha inland buffer zone. Pictured Rocks National Lakeshore is the only U.S. National Park with a legislated inland buffer zone; a concept which is more common for parks and biosphere reserves outside the U.S. (Shafer 1999).

The inland buffer zone is a mixture of federal, state, and private ownership. Initially, the inland buffer zone was implemented on behalf of the Cleveland-Cliffs Iron Company, to avoid a complete ban on commercial logging that would be typical for a National Park Service holding (http://www.nps.gov/piro/historyculture/upload/PRNL Administrative History.pdf). The company proposed that the bulk 
Fig. 1 The map shows the study area in light gray, consisting of Pictured Rocks National Lakeshore (park core zone and inland buffer zone) and a $2 \mathrm{~km}$ zone adjacent to the park. Note that the eastern most part of the park could not be analyzed due to lacking data from the Michigan Land Economy Survey (MLES)

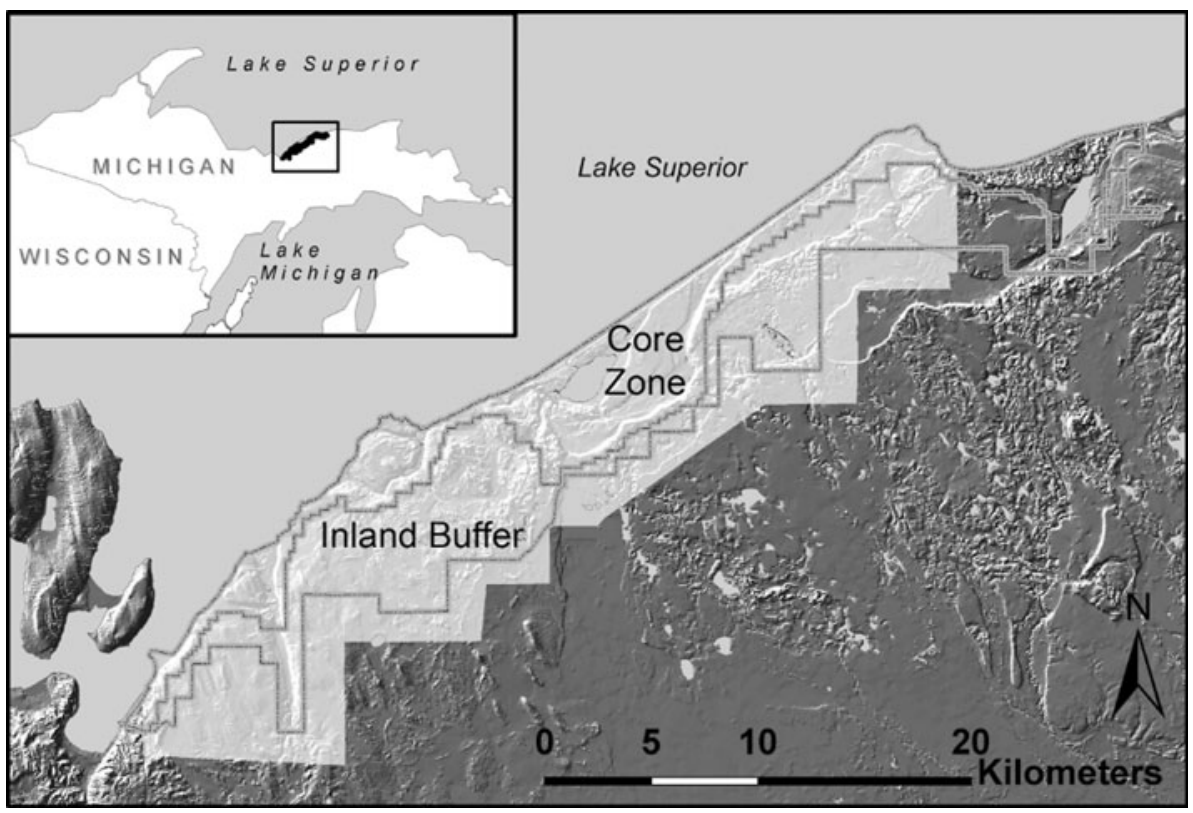

of timberlands within the park inland buffer zone be left in private ownership so long as they were managed for sustained yield and left accessible for public recreation. In return the Company promised to sell the lands within the core zone to the National Park Service, which were essential for scenic and recreational development (Vogel 2000). As a result, there are two areas with similar land-use history until 1966 that were split into a buffer area with continuing selective timber harvesting, and a core area with no timber harvest. This allows comparing patterns of change between the core and the inland buffer zone and to address the question of whether the land in the core zone has recovered more fully to pre-settlement conditions than land in the buffer zone. For further comparison, we also examined an area of 10,900 ha within a $2 \mathrm{~km}$ zone adjacent to the park boundary (Fig. 1).

\section{Land-Use History}

Human activities in the region have a long history. Archeological evidences prove human habitation during the Middle and Late Woodland period (ca. 3,000-300 years before present) in northern Michigan (Silbernagel and others 1997). In order to understand and interpret landcover and vegetation changes, we briefly outline here landuse history since the beginning of Euro-American settlement in the study region, with a particular focus on logging history. One of our main data sources was a dataset of logging activities within the park area from the mid 19th century until 2004. This dataset was compiled by the park service based on data collected by the Michigan Department of Natural Resources (MIDNR). The dataset represents documented activities of the most important logging companies that were active in the region during this period. The dataset provide spatially explicit data in a GIS vector format and includes information on the treatment (clear cut vs. selective logging) as well as the year of the logging activity but no information on tree species and size classes harvested. From this dataset, we calculated time series of logging activities for both park zones (core zone and inland buffer zone). Additionally, we compiled information from literature, documents from the Pictured Rocks National Lakeshore's archive and information on the park history published on the park's website (http://www.nps.gov/ piro/historyculture). Archival sources include written documents, particularly an unpublished manuscript written by the local historian Charles York on logging and mining history (York 2003), and numerous historical photographs illustrating the rich land-use history of the park.

Our land-use reconstruction based on these multiple sources confirmed that the entire study area was affected by intensive logging since the mid 18th century. The Land Economy Survey map from 1928 (detailed description of this source see below), for example, indicated a total of 42 logging camps (26 in the core zone and 16 in the inland buffer zone) and almost $20 \mathrm{~km}$ of logging railroads within the boundaries of the current protected area. Another five camps and some small settlements could be found on the same maps for the $2 \mathrm{~km}$ zone adjacent to the park. For the park core zone, our logging records show a clear peak of logging activities in the last 3 years before park establishment in 1966 but no logging was reported anymore after park establishment (Fig. 2). In the inland buffer zone in contrast, we observed a slight increase of logging activities after park establishment and increasing (selective) logging in the late 1990s. Unfortunately no 

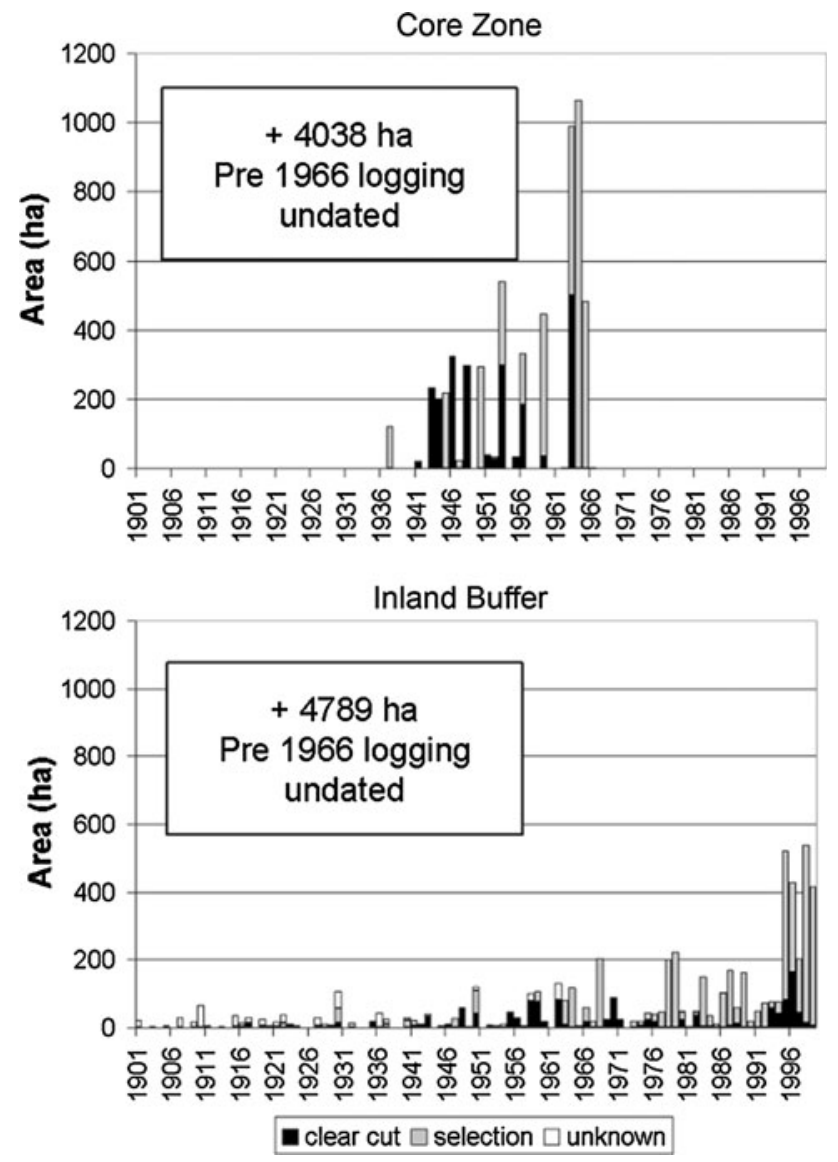

Fig. 2 Logging activities in the park core zone and the inland buffer zone 1900-1999

quantitative long-term logging data was available for the area adjacent to the park. However, more than $40 \%$ of all records do not provide information on the exact year and the type of logging. However, archival documents, particularly the unpublished manuscript by York (2003) suggest that most harvesting activities during the late 19th and early 20th century were clear-cuts, which was the typical logging regime at this time (Williams 1989). Still all of the logging-related information needs to be interpreted with caution due to its incompleteness and limitation in accuracy.

When the American Civil War ended in 1865, many of the South's furnaces had been destroyed, while the demand for iron boomed due to the westward expansion. During this era, many of the Upper Peninsula's furnaces were constructed, and local timber was used as charcoal. Near Munising at the western entrance to the today's park a blast furnace was constructed and operated starting in 1868. Many charcoal kilns were built within a few kilometers around the furnace. Hardwood species particularly maple and American beech was found to produce the most suitable charcoal (Mining history summarized on the national Lakeshore website: http://www.nps.gov/piro/historyculture).

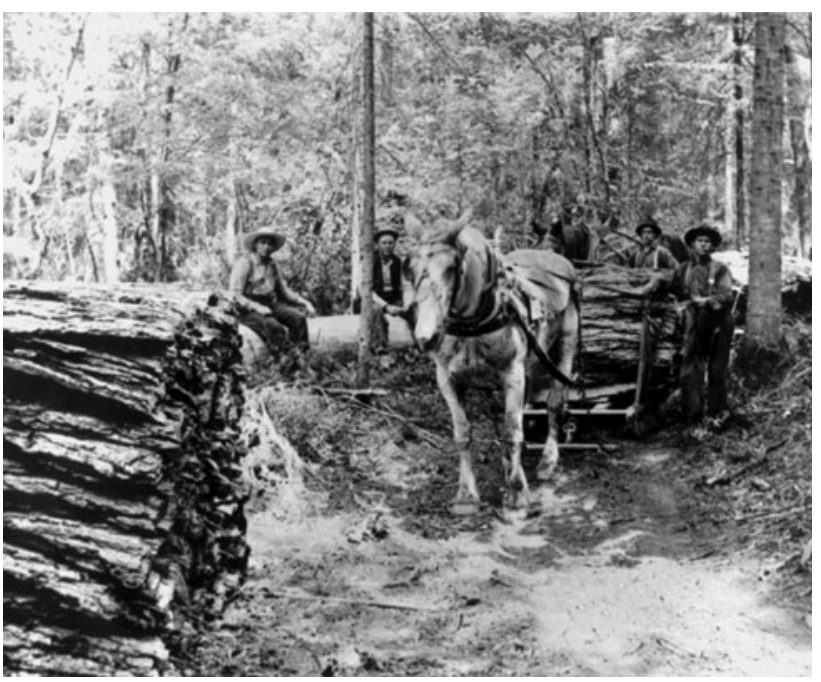

Fig. 3 Collecting hemlock bark (picture undated, source: Pictured Rocks National Lakeshore Archive)

Extensive logging activities started in the early 1880 s along the shoreline and in areas mainly stocked with white pines (York 2003). Between 1882 and 1909 over 1,200 ha of the extensive white pine forests were cut. During the operations, and in the years after these area also burned several times. As soon as the timber was exhausted in one area the temporary logging railroads were shifted to a new, not yet cut area. After the first phase of logging activities, during which mainly white pines were cut, the focus shifted at the turn of the century toward hardwoods. The western part of the park was most intensively used until 1938, while the eastern part was cut after 1940 for saw logs and pulpwood production. In addition, cedar was cut selectively for railroad ties, shingles, posts, and poles. Further, hemlock bark was an important raw material used in the tanning process to produce shoe leather. In 1896, a tannery was established in Munising. Precise quantitative and spatial information on hemlock bark exploitation is lacking but a note and a historical picture found in the Lakeshore's Archive illustrate the importance of this practice (Fig. 3). The note states that "millions of tons of hemlock bark from the surrounding area was used" until the company ceased operations in 1920.

Land-Cover and Vegetation Records

\section{General Land Office Survey (GLOS)}

The U.S. General Land Office Public Land Survey (GLOS) - also known as Public Land Survey - is the most important source for reconstructing vegetation prior to Euro-American settlement in the U.S. (Schulte and Mladenoff 2001) and to analyze land-cover and vegetation changes since then (Radeloff and others 1999; Manies and Mladenoff 2000; Rhemtulla and others 2007). The data 
were recorded from eastern Ohio to the West Coast between the late 18th century and the early 20th century (Stewart 1935). For the survey, land was divided into townships of 36 one-square-miles sections. The surveyors marked the intersections of section lines (section corners), midpoints between section corners (quarter corners), and those locations where section lines crossed a river or lake (meander corners) by placing posts or stones. At each of these corners they marked two to four witness trees (usually one per compass quadrant: NE, NW, SE, and SW) and recorded species, diameter, and location (relative to the corner). An overview on the benefits and limitations of this data source is given in Schulte and Mladenoff (2001).

For our study area, the GLOS was conducted between 1841 and 1855 . For the analysis, we used primarily a preinterpreted land-cover map provided by Comer and others 1995 (based on an earlier interpretation from Marschner and Perejda 1946) which is available as a GIS vector dataset. The map provides a classification of both landcover ( 7 types; 5 of which were present in our study area) and vegetation (66 types; 16 of which were present in our study area). Minimum mapping unit of this dataset within our study area was 0.25 ha. For selected tree species, we additionally used the original witness tree information of the total of 1,532 trees that were recorded.

\section{Michigan Land Economy Survey}

The Michigan Land Economy Survey (referred to a "Land Economic Survey" in the following) was conducted in the late 1920s at the height of the agricultural expansion in the State (De Vries 1928). The maps are similar to the Wisconsin Land Economic Inventory maps-the so-called Bordner Report (State of Wisconsin 1936) - which have been successfully used for studies of land-cover and vegetation change (Bürgi and Turner 2002; Rhemtulla and others 2009a, b). For the study area, two map sheets from The Land Economic Survey were available in the Pictured Rocks National Lakeshore Archive (Fig. 4). Unfortunately, one Land Economic Survey map for the eastern most part of Pictured Rocks was missing (16\% of the total park area) and despite intensive search these sheets could not be found in other archives. The maps provide hand-drawn information on land-cover types, agricultural land-use, and tree species composition for forest stands (including different classes for stand density and average diameter; information not used in this study) for a median patch size of 8.8 ha in the study area and a minimum mapping unit of 0.2 ha. Additionally, the maps provide information on logging activities as they indicated the location of logging camps and logging railroads. We scanned the available map sheets and georectified and vectorized the map information by hand in ArcGIS 9.3 software.

\section{Modern Land-Cover and Vegetation}

Information on modern land-cover and vegetation was obtained from a vegetation map established by the MIDNR. The map is based on a combination of 1994 color infrared aerial photographs and Landsat Thematic Mapper
Fig. 4 Sample of the Michigan Land Economic Survey map from the central part of the Pictured Rocks National Lakeshore. The area shown is dominated by northern hardwood and hemlockhardwood forest types $(M b$ maple, beech; $H$ hemlock, maple, yellow birch) with relatively large diameters (15+: 15 inch an more)

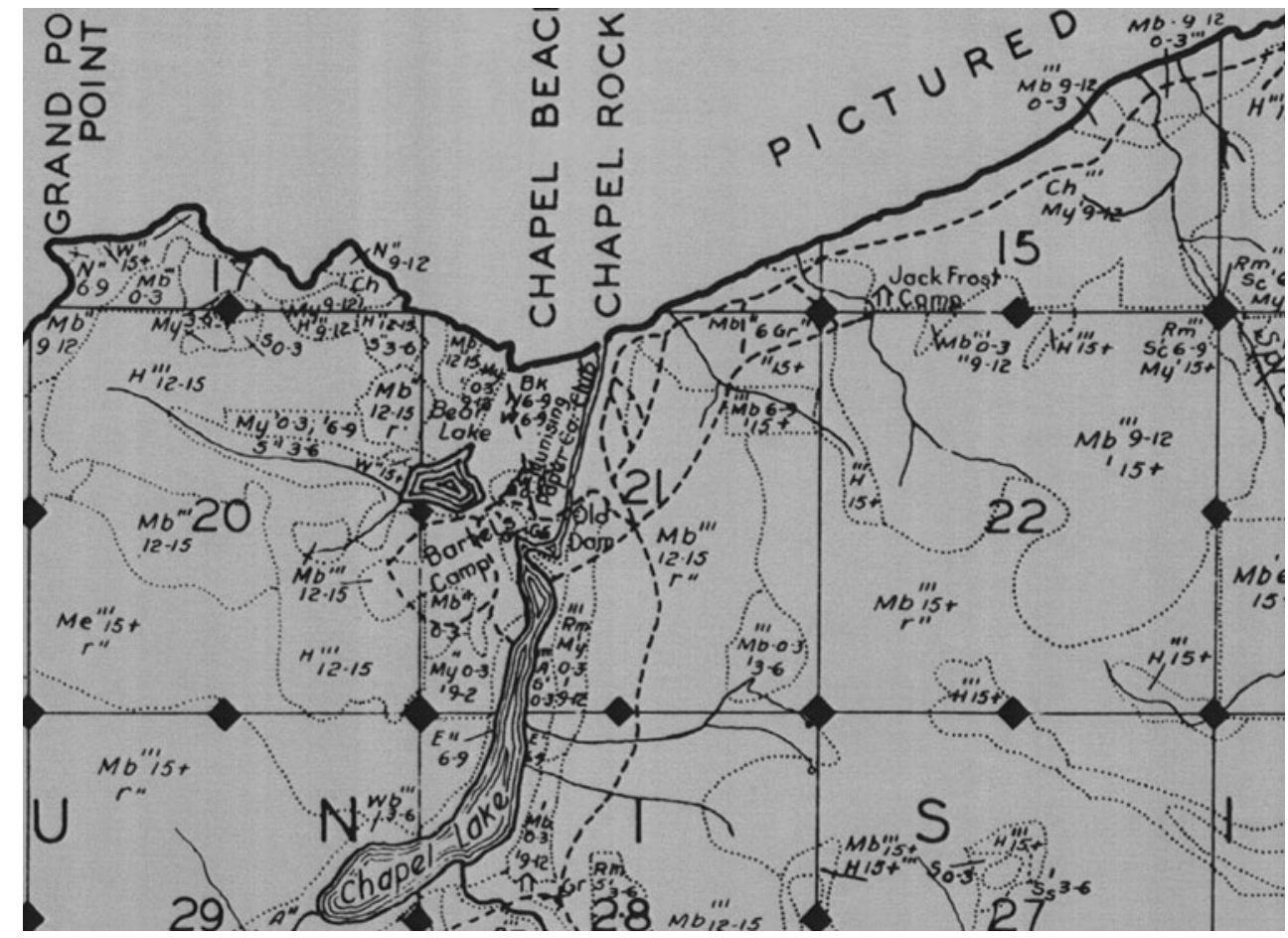


Table 1 Consistent classification scheme for land-cover (level 1) and forest community (level 2) based on the original information from GLOS (classification by Comer and others 1995), Michigan Land Economy Survey (MLES), and modern vegetation data sets

\begin{tabular}{|c|c|c|c|c|}
\hline Level 1 & Level 2 & $\begin{array}{l}\text { GLO (classification by } \\
\text { Comer and others 1995) }\end{array}$ & MLES & Modern \\
\hline \multirow[t]{8}{*}{ Forest } & Early succession & $\begin{array}{l}\text { NA (not present in study } \\
\text { area) }\end{array}$ & $\begin{array}{l}\text { If dominant species is either white } \\
\text { birch, paper birch, or cherry }\end{array}$ & Aspen/Birch \\
\hline & Northern hardwood & $\begin{array}{l}4111 \text { Beech, sugar maple, } \\
\text { yellow birch }\end{array}$ & $\begin{array}{l}\text { If the two most dominant tree species } \\
\text { are northern hardwood species }\end{array}$ & $\begin{array}{l}\text { Sugar maple } \\
\text { Maple hardwoods } \\
\text { Red maple }\end{array}$ \\
\hline & \multirow[t]{2}{*}{ Hardwood/conifer } & 4119 Beech, hemlock & $\begin{array}{l}\text { If first species is northern hardwood } \\
\text { and second any conifer species }\end{array}$ & \multirow[t]{2}{*}{ Hardwood/conifer } \\
\hline & & 4228 Hemlock, sugar maple & $\begin{array}{l}\text { If first species is a Conifer and second } \\
\text { a Hardwood species }\end{array}$ & \\
\hline & \multirow[t]{2}{*}{ Pine forest } & 4211 White pine & If both species are pine species & Red/white pine \\
\hline & & $\begin{array}{l}4216 \text { Red pine, white pine } \\
4227 \text { White pine, hemlock } \\
333 \text { Pine barrens }\end{array}$ & $\begin{array}{l}\text { If first species is a pine species and } \\
\text { second any other conifer species }\end{array}$ & $\begin{array}{l}\text { Jack pine } \\
\text { Red pine } \\
\text { Red/white/jack pine }\end{array}$ \\
\hline & \multirow[t]{2}{*}{ Other conifers } & 4223 Fir, spruce, cedar & $\begin{array}{l}\text { If both species are conifer species but } \\
\text { not pine species }\end{array}$ & \multirow[t]{2}{*}{ Hemlock } \\
\hline & & 4226 Hemlock & $\begin{array}{l}\text { If first species is a conifer but not pine } \\
\text { and second is a pine species }\end{array}$ & \\
\hline Forested wetland & Other conifers & $\begin{array}{l}4231 \text { Cedar swamp } \\
423 \text { Mixed conifer swamp }\end{array}$ & $\begin{array}{l}\text { If patch is indicated as wetland type } \\
\text { and at least one conifer species is } \\
\text { listed }\end{array}$ & $\begin{array}{l}\text { Cedar } \\
\text { Wetland conifer }\end{array}$ \\
\hline \multirow[t]{2}{*}{ Wetland } & \multirow[t]{2}{*}{ Non-forest } & $\begin{array}{l}6122 \text { Alder, Willow } \\
6221 \text { Emergent Marsh }\end{array}$ & \multirow[t]{2}{*}{$\begin{array}{l}\text { If patch is indicated as wetland type } \\
\text { but no tree species are listed }\end{array}$} & $\begin{array}{l}\text { Wetland shrub } \\
\text { Wetland shrub- } \\
\text { marsh }\end{array}$ \\
\hline & & 6224 Wet meadow & & Wetland shrub-bog \\
\hline \multirow[t]{2}{*}{ Open land } & & 72 Sand dune & Agricultural land & $\begin{array}{l}\text { Cleared area/non- } \\
\text { forest }\end{array}$ \\
\hline & & 744 Exposed bedrock & $\begin{array}{l}\text { Bracken dominant } \\
\text { Briar dominant } \\
\text { Sand/beach }\end{array}$ & Dune \\
\hline
\end{tabular}

data from 2000/2001. The map includes 19 land-cover types including 11 forest types at 30-m raster resolution.

\section{Homogenizing Classification Schemes from Different Time Points}

Establishing a consistent classification over time is a major challenge when working with historical land-cover data from different sources and different backgrounds (e.g., Rhemtulla and others 2007). At the same time, a consistent classification scheme is a prerequisite for an as unbiased as possible analysis of changes over the entire study period. We developed a classification scheme that could be applied consistently to all three datasets for two different levels of ecological detail: land-cover types and forest communities (Table 1). Unfortunately, changes at the tree species level could not be analyzed systematically because information was too heterogeneous across the three datasets. Both the GLO and the Land Economy survey provide relatively detailed but not uniform information on tree species composition (witness trees vs. species occurrence in forest stands). In contrast, such information was lacking in our most recent dataset. However, we addressed some changes in species composition based on our limited datasets in the discussion section (see below).

All GIS processing was conducted in ArcGIS 9.3. In a first step, we reclassified the original land-cover and forest vegetation information into the classification scheme presented in Table 1 . The resulting three vector datasets (one for each point in time) were converted to raster datasets with 1 ha resolution. We then calculated relative abundance for both land-cover and forest community types and for all three points in time (pre-settlement conditions in 1850, time of maximum agricultural expansion in 1928, and modern conditions) and for all zones (core zone, buffer zone, and zone adjacent to the park). Finally, a change matrix for each pixel was calculated in order to track trajectories of change and assess 
similarity between initial and modern conditions as well as continuity in land-cover and forest community over the entire study period (1850-1928-2000). As we analyzed a complete enumeration (or a census) and not a sample, we considered any change among time periods and differences across zones as significant.

\section{Naturalness Assessment}

Based on the information on changes in land-cover and forest community types since pre-settlement, we established a scheme to assess the naturalness of the current landscape under consideration of its historical development (Table 2). The scheme distinguishes between similarity (same conditions in 1850 and 2000) and continuity (1850-1928-2000). The naming of naturalness categories follows the terminology used by Machado (2004), but we reduced the original 11 classes to six that indicated a gradient from natural virgin to transformed landscapes (Table 2). Areas with continuous land-cover and forest communities were assigned to the highest category of naturalness (category 1, natural virgin). The next two categories (category 2, natural and category 3, sub-natural) still feature continuous forest cover but changes in forest community. Category 4 (semi-natural) indicates similarity in land-cover between pre-settlement and current condition, but a lack of continuity (e.g., no forest cover at the mid-point of our time series, but forest at both endpoints). The lowest degree of naturalness was reflected in category 5 (semi-transformed) with land-cover similarity only and category 6 (transformed) which displays no similarity in either land-cover or forest type.

\section{Results}

Changes in Land-Cover

Forest was by far the dominant land-cover time in all time points despite a substantial reduction of forest cover in the first period (1850-1928) particularly in the inland buffer zone (from 87 to $80 \%$ ) and the region adjacent to the park (from 86 to $73 \%$ ) (Table 3 ). In the same period, we also found a slight reduction of the forested wetlands (from 14 to $12 \%$ ) and an increase in open land-cover (from 0.3 to $9.3 \%$ ). Despite being heavily logged in the late 1800s and early 1900s, modern land-cover is remarkably close to the pre-settlement conditions especially for the areas inside the park.

Landscape continuity is by far the dominant trajectory over the whole study period. $73 \%$ of the total study area remained in the same land-cover class in all three time points. However, there was a clear gradient in landscape continuity from the park core zone $(81 \%)$ to the inland buffer zone $(74 \%)$ and the area outside the park $(66 \%)$. For forest cover alone, continuity amounted to $80 \%$, again with highest values for the park core zone (89\%) and lower values in the inland buffer zone $(80 \%)$ and the area adjacent to the park (74\%). The second important trajectory was the conversion of forests to open land between 1850 and 1928 and the subsequent recovery back to forest. $9 \%$ of the area initially covered by forests experienced this type of transformation. This type of trajectory was more frequent around the park (12\%), and the inland buffer zone $(11 \%)$, than in the core zone $(2 \%)$. Only $5 \%$ of all forests that were converted to open land by 1928 did not return back to forest.

\section{Changes in Forest Community Types}

In all three zones, northern hardwood forest was the dominating forest type in all time points featuring only relatively small changes (Table 4 ). The biggest change in any forest type occurred in the pine forests with a clear drop from pre-settlement to 1928 following a somewhat muted recovery until 2000. This particularly holds true for the inland buffer zone, which had initially the largest proportion of pine forests. The proportion of early succession forests was highest in 1928 with particularly high values in the park core zone.

Table 2 Naturalness categories based on trajectories of change of land-cover and forest community types

\begin{tabular}{lllll}
\hline & $\begin{array}{l}\text { Land-cover } \\
1850-1928-2000\end{array}$ & $\begin{array}{l}\text { Land-cover } \\
1850 / 2000\end{array}$ & $\begin{array}{l}\text { Forest community } \\
1850-1928-2000\end{array}$ & $\begin{array}{l}\text { Forest community } \\
1850 / 2000\end{array}$ \\
\hline Category 1 (natural virgin) & Continuous & $=$ & Continuous & $=$ \\
Category 2 (natural) & Continuous & $=$ & Not continuous & Not continuous \\
Category 3 (sub-natural) & Continuous & $=$ & Not continuous & $=$ \\
Category 4 (semi-natural) & Not continuous & $=$ & Not continuous & $\neq$ \\
Category 5 (semi-transformed) & Not continuous & $=$ & Not continuous & $\neq$ \\
Category 6 (transformed) & Not continuous & $\neq$ &
\end{tabular}

Naming of naturalness categories modified after the classification introduced by Machado (2004) 
Table 3 Changes in relative abundance of land-cover classes (level 1) from pre-settlement conditions (1850) to date for total study area, the park core zone, inland buffer zone, and the reference area outside the park

\begin{tabular}{lllll}
\hline & Forest & $\begin{array}{l}\text { Forested } \\
\text { wetland }\end{array}$ & Wetland & Open land \\
\hline Total area & & & & .003 \\
GLO (1850) & .849 & .143 & .005 & .093 \\
MLES (1928) & .779 & .120 & .008 & .028 \\
MODERN (2000) & .851 & .109 & .010 & .012 \\
Park core zone & & & .003 & .023 \\
GLO (1850) & .811 & .175 & .010 & .011 \\
MLES (1928) & .815 & .151 & .013 & .000 \\
MODERN (2000) & .822 & .154 & .003 & .101 \\
Park inland buffer zone & & & .007 & .017 \\
GLO (1850) & .867 & .130 & .007 & .000 \\
MLES (1928) & .796 & .097 & .007 \\
MODERN (2000) & .854 & .122 & .007 & .144 \\
Outside park & & & .000 & \\
GLO (1850) & .861 & .132 & .120 & \\
MLES (1928) & .728 & .057 & & \\
MODERN (2000) & .873 & & & \\
\hline
\end{tabular}

Trajectories of change of the northern hardwood forest types were found to be rather persistent. $76 \%$ of the initially 15,600 ha northern hardwood forests remained in the same class over the whole study period. Only a few (6\%) of northern hardwood forests were converted to either nonforest or early succession forest types until 1928. In contrast, only $11 \%$ of the pine forests showed continuity over the whole study period. More than $50 \%$ of the initial pine forests switched to either non-forest or early succession forest types in 1928 and most of them (83\%) recovered back to pine forest or mixed hardwood/conifer forest types.

\section{Naturalness of the Landscape}

More than half of the study area (54\%) was considered as natural virgin (category 1 ) according to our measure of the landscape's naturalness (Fig. 5). The portion was slightly higher in the park zone (56\% for each the core and the inland buffer zone) than in the area adjacent to the park (49\%). Another $20 \%$ of the entire study area falls into categories 2 and 3 indicating continuity in land-cover but changes in the forest community type. Here, the highest values were found for the park core zone $(25 \%)$ and lower values for the inland buffer zone $(20 \%)$ and the area outside the park (17\%). In contrast, areas that completely converted over the study period (category 6) were more abundant outside the park (19\%) than in the park area (11\% for both the core and the inland buffer zone).

We found the largest patches of high naturalness in the large contiguous areas dominated by northern hardwoods, while the majority of pre-settlement pine forests fall into categories 3 (sub-natural) and 4 (semi-natural). We observed a rather inconsistent pattern for forests initially dominated by other conifers where about $40 \%$ were considered as natural virgin (category 1 ) and the same portion was completely transformed (category 6).

\section{Discussion and Conclusion}

In pre-settlement times, the conditions in the park core zone, the inland buffer zone, and the reference area around the park were very similar both in terms of land-cover and forest communities. However, different land-use regimesespecially after park establishment-resulted in distinct land-cover and vegetation trajectories. Land-use abandonment led to a recovery toward initial conditions in the core zone, selective logging in the inland buffer preserved the conditions at the time of park establishment, and ongoing commercial logging outside the park led to continued land transformations.

As a result, the core zone showed the largest degree of similarity between pre-settlement and current times. The high similarity between today's landscape and vegetation with pre-settlement conditions, especially in the core zone of Pictured Rocks National Lakeshore, highlights the ability of temperate forest ecosystems to recover from past human disturbances within relatively short time (Gimmi and others 2009). The portion of the landscape that is similar to its pre-settlement state is relatively high compared to the entire northern U.S. Great Lakes region (Schulte and others 2007) and to Wildlife Refuges of the Upper Midwest (Corace and others 2012). One reason might be the relatively low portion of land that came under 
Table 4 Changes in relative abundance of forest community classes (level 2) from presettlement conditions (1850) to date for total study area, the park core zone, inland buffer zone, and the reference area outside the park

\begin{tabular}{|c|c|c|c|c|c|c|}
\hline & $\begin{array}{l}\text { Northern } \\
\text { hardwood }\end{array}$ & $\begin{array}{l}\text { Hardwood/ } \\
\text { conifer }\end{array}$ & $\begin{array}{l}\text { Pine } \\
\text { forest }\end{array}$ & $\begin{array}{l}\text { Other } \\
\text { conifers }\end{array}$ & $\begin{array}{l}\text { Early } \\
\text { succession }\end{array}$ & $\begin{array}{l}\text { Non- } \\
\text { forest }\end{array}$ \\
\hline \multicolumn{7}{|l|}{ Total area } \\
\hline GLO (1850) & .612 & .028 & .206 & .145 & .000 & .008 \\
\hline MLES (1928) & .572 & .055 & .030 & .163 & .079 & .101 \\
\hline MODERN (2000) & .601 & .091 & .146 & .111 & .013 & .039 \\
\hline \multicolumn{7}{|l|}{ Park core zone } \\
\hline GLO (1850) & .630 & .000 & .178 & .178 & .000 & .015 \\
\hline MLES (1928) & .527 & .051 & .025 & .230 & .134 & .033 \\
\hline MODERN (2000) & .576 & .164 & .075 & .160 & .001 & .024 \\
\hline \multicolumn{7}{|c|}{ Park inland buffer zone } \\
\hline GLO (1850) & .607 & .010 & .250 & .130 & .000 & .003 \\
\hline MLES (1928) & .601 & .055 & .034 & .130 & .073 & .107 \\
\hline MODERN (2000) & .621 & .084 & .139 & .122 & .011 & .024 \\
\hline \multicolumn{7}{|l|}{ Outside park } \\
\hline GLO (1850) & .604 & .074 & .178 & .136 & .000 & .008 \\
\hline MLES (1928) & .576 & .057 & .030 & .147 & .041 & .151 \\
\hline MODERN (2000) & .598 & .036 & .215 & .057 & .024 & .070 \\
\hline
\end{tabular}

Fig. 5 Map of naturalness of the study area, including a bar graph showing the percentage of each naturalness category for the park core zone, the inland buffer zone, and the study area outside the park boundaries

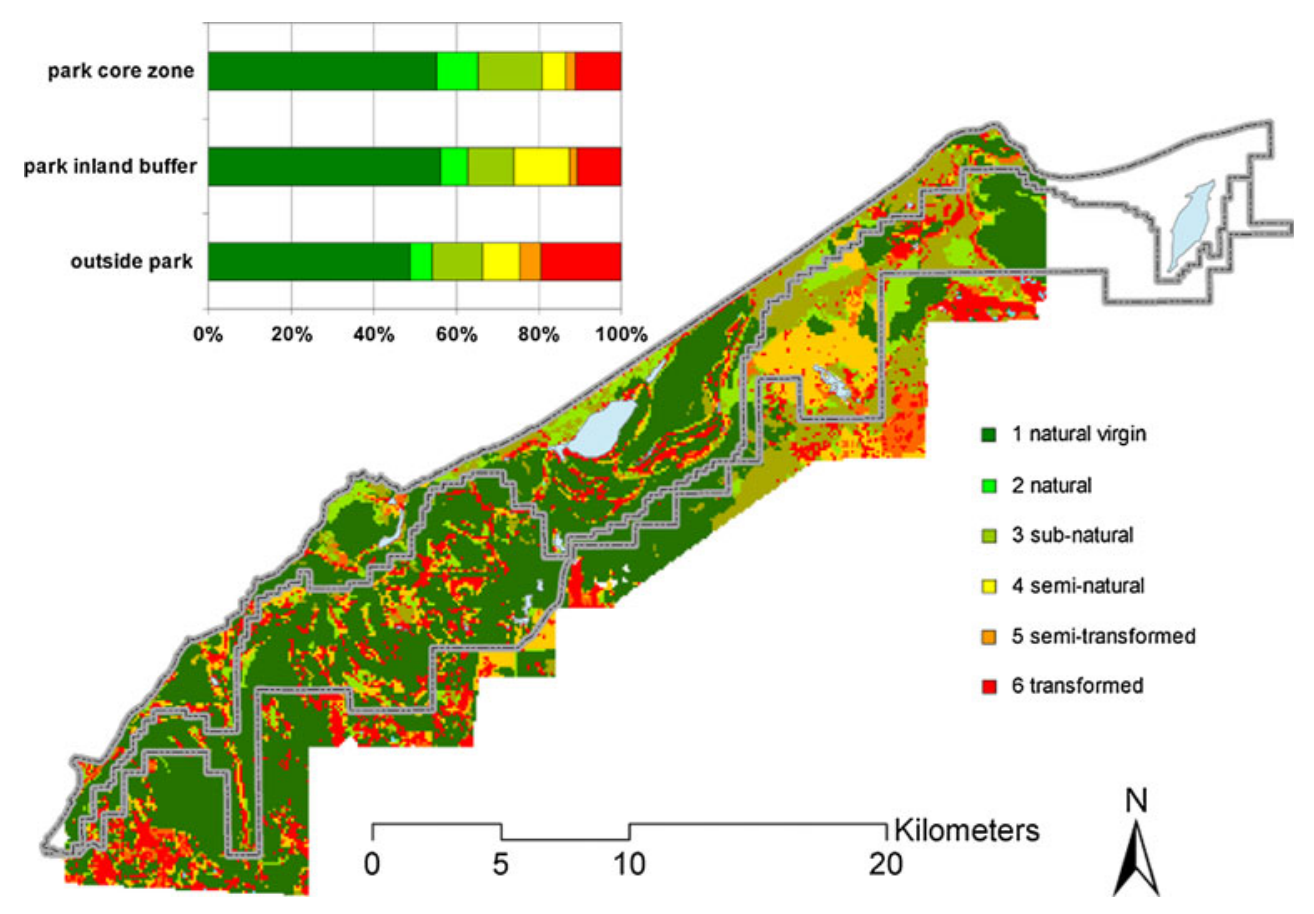

agricultural use after forest clearing. Only 335 ha (1\% of the entire study area or $11 \%$ of the cleared forest area) were used for agriculture in 1928. The lack of a more widespread and relatively short phase of agricultural landuse meant that seed banks most likely persisted and soil properties did not change fundamentally so that a regrowth of the initial forest community type was possible (Bossuyt and Hermy 2009).

For both the land-cover and the forest community level, continuity was the most dominant pattern. This is also reflected by the large proportion of the landscape considered as categories 1-3 in our naturalness assessment. Continuity was clearly higher at the land-cover level though than at the forest community level, a factor that should be considered in forest transition studies for example. At the level of tree species and forest structure, there were probably even more changes. Abundance of eastern hemlock, for example, likely decreased rapidly since pre-settlement due to bark removal for the local tanning industry. Similarly, a rapid reduction of white pine 
in the study area likely was the result of the massive exploitation (Steen-Adams and others 2007). In contrast, the expansion of red pine plantations with homogenous stand structure is likely an important reason for the large increase of pine forest outside the park area since 1928. Such changes are not appropriately reflected when conducting analyses only at the level of land-cover and forest communities. Including data on tree species and forest structure would likely change our interpretation of the landscape's naturalness. While a landscape may be considered as natural regarding to the continuity of forest cover, the same landscape may be assessed as strongly transformed when including information on tree species composition and forest structure. Recovering forest area after forest clearing does not necessarily imply a return to a more natural state, and analyzing forest cover data alone may mask that forest composition and structure shifted into a new state. Crown and others (2002), for example, found much more complex stand structure in unmanaged oldgrowth sugar maple dominated forest on Michigan's Upper Peninsula compared to relatively uniform structure secondgrowth forests of the same type. Anyway, late-successional composition and structure will reestablish only after extremely long periods without major disturbance (Woods 2000).

However, changes on species and structure level are difficult to quantify due to a lack of appropriate modern (!) data. While the GLO and Land Economy Survey data permit reconstructing changes at the species level, and even provide data on forest structure, appropriate modern data for comparison were unfortunately lacking. The USDA forest inventory (FIA) data provides species level data but their spatial resolution is too coarse to be useful at scales such as in our study (Wang and others 2009). The lack of species level data for the modern era is not surprising, because re-surveying the landscape with the historical methods would be enormously labor- and hence cost-intensive, but it remains unfortunate that no other data sources can fill this gap. Alternatively, modern-albeit costly-remote sensing techniques (particularly LiDAR data) might provide interesting insights in current forest composition and structure.

Apart from tree species and forest structure, there are several other aspects which could be additionally included to assess naturalness of the landscape in more encompassing way (Povilitis 2002). For example, the distance to existing anthropogenic features such as houses and roads (Gimmi and others 2011) might be a suitable indicator for the naturalness of an area.

Another important factor that should be included in a more encompassing naturalness assessment is the similarity of historic and recent natural disturbance regime (Radeloff and others 2000). This would allow integrating the natural range of variability (Fule and others 1997) into such an assessment, thereby incorporating the dynamic nature of many natural ecosystems more explicitly. The northern Great Lakes region is characterized by a relatively low frequency disturbance regime. Severe wind disturbance was infrequent in pre-settlement times (rotation period of several millennia), resulting in the dominance of late succession (mature) forest types such as northern hardwood and hemlock-hardwood forests (Frelich and Lorimer 1991). Infrequent stand replacing fires on areas with better drained soils maintained pine forest community types (Schulte and Mladenoff 2005; Schulte and others 2005). The changes we observed for land-cover (high proportion of trajectory forest-open land-forest) and in forest community types form more mature types (Northern Hardwood, Hardwood/ Conifer) in pre Euro-American settlement time to early successional types in 1928 clearly exceeds the rates of change we could expect under natural conditions. However, including dynamics of natural ecosystems into a naturalness assessment would require a look a much larger areas and timescales then we did in our case study.

Despite these shortcoming though, our study highlights the need for historical context to understand the current state of the landscape and demonstrates the value of historical land-cover change information for the assessment of naturalness. Our results show that the park was effective in preserving a landscape close to its natural state also in the buffer zone of the park, where sustainable logging is still part of the management concept. Overall the degree of naturalness was fairly high in the entire study area but with considerable difference between the park zones and the area in its immediate surroundings. Our results are particularly robust as our analysis was based on a complete census of the study area and not of a sample. It is very likely that this difference would be much more pronounced for parks located in more human-dominated parts of the Great Lakes region such as Indiana Dunes National Lakeshore (Gimmi and others 2011). The results provide vital information for park managers to set appropriate conservation targets and restoration priorities, for example, regarding to the potential establishment of a wilderness area within the existing park boundaries. Such an area should ideally include those areas of the park that have uninterrupted habitat continuity and the least land-use legacies.

Acknowledgments We gratefully acknowledge support by the National Park Service's Great Lakes Inventory and Monitoring Program. Comments by three anonymous reviewers and the editor greatly strengthened our manuscript. D. Mladenoff and his team supported the work by sharing their experience of working with GLO data. We also thank S. Schmidt and D. Helmers for their GIS support. Further, we appreciated the help from the National Park Service staff at Pictured Rocks National Lakeshore. 


\section{References}

Anderson JE (1991) A conceptual framework for evaluating and quantifying naturalness. Conserv Biol 5:347-352

Angermeier PL (2000) The natural imperative for biological conservation. Conserv Biol 14:373-381

Barry CR, Rooney TP, Ventura SJ, Waller DM (2001) Evaluation of biodiversity value based on wildness: a study of Western Northwoods, Upper Great Lakes, USA. Nat Areas J 21:229-242

Bolliger J, Schulte LA, Burrows SN, Sickley TA, Mladenoff DJ (2004) Assessing ecological restoration potentials of Wisconsin (USA) using historical landscape reconstructions. Restor Ecol 12:124-142

Bossuyt M, Hermy M (2009) Influence of land-use history on seed bank in forest ecosystems. Ecography 24:225-238

Brandt JS, Kuemmerle T, Haomin L, Guopeng R, Jianguo Z, Radeloff VC (2012) Ecotourism accelerates old-growth forest logging in southwest China despite the national logging ban. Remote Sens Environ 121:358-369

Branquart E, Verheyen K, Latham J (2008) Selection criteria of protected forest area in Europe: the theory and the real world. Biol Conserv 141:2795-2806

Bürgi M, Turner MG (2002) Factors and processes shaping land cover and land cover changes along the Wisconsin River, USA. Ecosystems 5:184-201

Comer PJ, Albert DA, Wells HA, Hart BL, Raab JB, Price DL, Kashian DM, Corner RA, Schuen DW (1995) Michigan's native landscape, as interpreted from the General Land Office Surveys 1816-1856. Report to the USEPA. Water Division and the Wildlife Division and Michigan Department of Natural Resources. Michigan Natural Features Inventory, Lansing, Michigan

Corace RG III, Shartell LM, Schulte LA, Brininger WL, McDowell MKD, Kashian DM (2012) An ecoregional context for forest management on National Wildlife Refuges of the Upper Midwest, USA. Environ Manage 49:359-371

Crown TR, Buckley DS, Nauertz EA, Zasda JC (2002) Effects of management on the composition and structure of northern hardwood forests in upper Michigan. For Sci 48:129-145

De Vries W (1928) The Michigan Land Economic Survey. J Farm Econ 10:516-524

DeFries R, Hansen AJ, Newton AC, Hansen MC (2005) Increasing isolation of protected areas in tropical forests over the past twenty years. Ecol Appl 15:19-26

Dudley N (ed) (2008) Guidelines for applying protected area management categories. IUCN Gland

Foley JA, DeFries R, Asner GP, Barford C, Bonan G, Carpenter SR, Chapin FS, Coe MT, Daily GC, Gibbs HK, Helkowski JH, Holloway T, Howard EA, Kucharik CJ, Monfreda C, Patz JA, Prentice IC, Ramankutty N, Snyder PK (2005) Global consequences of land use. Science 309:570-574

Foster D, Swanson F, Aber J, Burke I, Brokaw N, Tilman D, Knapp A (2003) The importance of land-use legacies to ecology and conservation. Bioscience 53:77-88

Frelich LE, Lorimer CG (1991) Natural disturbance regimes in hemlock-hardwood forests of the Upper Great Lakes region. Ecol Monogr 61:145-164

Fule PZ, Covington WW, Moore MM (1997) Determining reference conditions for ecosystem management in southwestern ponderosa pine forests. Ecol Appl 7:895-908

Gimmi U, Wolf A, Bürgi M, Scherstjanoi M, Bugmann H (2009) Quantifying disturbance effects on vegetation carbon pools in mountain forests based on historical data. Reg Environ Change 9:121-130

Gimmi U, Schmidt SL, Hawbaker TJ, Alcantara C, Gafvert U, Radeloff VC (2011) Increasing development in the surroundings of U.S. National Park Service holdings jeopardizes park effectiveness. J Environ Manage 92:229-239

Goudie AS (2006) The human impact on the natural environment. Past, present and future. Blackwell, Oxford

Heckenberger MJ, Kuikuro A, Kuikuro UT, Russell JC, Schmidt M, Fausto C, Franchetto B (2003) Amazonia 1492: Pristine forest or cultural parkland. Science 301:1710-1714

Machado A (2004) An index of naturalness. J Nat Conserv 12:95-110

Manies KL, Mladenoff DJ (2000) Testing methods to produce landscape-scale presettlement vegetation maps from the US public land survey records. Landsc Ecol 15:741-754

Marschner FJ, Perejda AD (1946) Original forests of Michigan (map). Wayne State University Press, Detroit

Mather AS (1992) The forest transition. Area 24:367-379

Meyfroidt P, Lambin E (2011) Global forest transition: prospects for an end to deforestation. Ann Rev Environ Resour 36:343-371

Moore MM, Covington WW, Fulé PZ (1999) Reference conditions and ecological restoration: a southwestern Ponderosa Pine perspective. Ecol Appl 9:1266-1277

Povilitis T (2002) What is a natural area? Nat Areas J 21:70-74

Radeloff VC, Mladenoff DJ, He HS, Boyce MS (1999) Forest landscape change in the northwestern Wisconsin pine barrens from pre-European settlement to the present. Can J For Sci 29:1649-1659

Radeloff VC, Mladenoff DJ, Boyce MS (2000) A historical perspective and future outlook on landscape scale restoration in the northwest Wisconsin Pine Barrens. Restor Ecol 8:119-126

Radeloff VC, Stewart SI, Hawbaker TJ, Gimmi U, Pidgeon AM, Flather CH, Hammer RB, Helmers DP (2010) Housing growth in and near United States protected areas limits their conservation value. Proc Natl Acad Sci USA 107:940-945

Ramankutty N, Heller E, Rhemtulla J (2010) Prevailing myths about agricultural abandonment and forest regrowth in the United States. Ann Assoc Am Geogr 100:1-11

Rhemtulla JM, Mladenoff DJ, Clayton MK (2007) Regional land-cover conversion in the U.S. Upper Midwest: magnitude of change and limited recovery (1850-1935-1993). Landsc Ecol 22:57-75

Rhemtulla JM, Mladenoff DJ, Clayton MK (2009a) Legacies of historical land use on regional forest composition and structure in Wisconsin, USA (mid- 1800s-1930s-2000s). Ecol Appl 19: 1061-1078

Rhemtulla JM, Mladenoff DJ, Clayton MK (2009b) Historical forest baselines reveal potential for continues carbon sequestration. Proc Natl Acad Sci USA 106:6082-6087

Rudel TK, Coomes OT, Moran E, Achard R, Angelsen A, Xu J, Lambin E (2005) Forest transitions: towards a global understanding of land use change. Glob Environ Change 15:23-31

Sanderson EW, Jaiteh M, Levy MA, Redford KH, Wannebo AV, Woolmer G (2002) The human footprint and the last of the wild. Bioscience 52:891-904

Schulte LA, Mladenoff DJ (2001) The original U.S. Public Land Survey records: their use and limitations in reconstructing preEuropean settlement vegetation. J For 99:5-10

Schulte LA, Mladenoff DJ (2005) Severe wind and fire regimes in northern forests: historical variability at the regional scale. Ecology 86:431-445

Schulte LA, Mladenoff DJ, Burrows SN, Sickley TA, Nordheim EV (2005) Spatial controls of pre-Euro-American wind and fire disturbance in Northern Wisconsin (USA) forest landscapes. Ecosystems 8:73-94

Schulte LA, Mladenoff DJ, Crow TR, Merrick LC, Cleland DT (2007) Homogenization of northern U.S. Great Lakes forests due to land use. Landsc Ecol 22:1089-1103

Shafer CL (1999) US national park buffer zones: historical, scientific, social and legal aspects. Environ Manage 23:49-73 
Silbernagel J, Martin SR, Gale MR, Chen J (1997) Prehistoric, historic, and present settlement patterns related to ecological hierarchy in the Eastern Upper Peninsula of Michigan U.S.A. Landsc Ecol 12:223-240

State of Wisconsin (1936) Division of Land Economic Inventory, Executive Office, Bulletin 3, Madison

Steen-Adams MM, Langston NE, Mladenoff DJ (2007) White pine in the northern forests: and ecological and management history of white pine on the Bad River Reservation of Wisconsin. Environ Hist 12:614-648

Stein ED, Dark S, Longcore T, Grossinger R, Hall N, Beland M (2010) Historical Ecology as a tool for assessing landscape change and informing wetland restoration priorities. Wetlands 30:589-601

Stewart LO (1935) Public land surveys: history, instructions, methods. Collegiate Press Inc., Ames

Swetnam TW, Allen CD, Betancourt JL (1999) Applied historical ecology: using the past to manage for the future. Ecol Appl 9:1189-1206
Vitousek PM, Mooney HA, Luchenko J, Melillo JM (1997) Human domination of earth's ecosystems. Science 277:494-499

Vogel J (2000) History of fish and fisheries in Pictured Rocks National Lakeshore. Pictured Rocks Resource Report 2000-1

Wang YC, Kronenfeld BJ, Larsen CPS (2009) Spatial distribution of forest landscape change in western New York from presettlement to the present. Can J For Res 39:76-88

Williams M (1989) Americans and their forests. A historical geography. Studies in environment and history, Cambridge University Press, Cambridge

Willis KJ, Gillson L, Brncic TM (2004) How "virgin" is virgin rainforest? Science 304:402-403

Woods KD (2000) Dynamics in late-successional hemlock-hardwood forests over three decades. Ecology 81:110-126

York C (2003) Timber, minerals, railroads in Alger County. Unpublished manuscript, donated to Pictured Rocks National Lakeshore Archive, Munising 